\title{
Skripsi
}

\section{PENGARUH RISIKO KEUANGAN, DIVIDEN, KEPEMILIKAN MANAJERIAL DAN REPUTASI AUDITOR TERHADAP PERATAAN \\ LABA}

(Studi Empiris pada perusahaan yang terdaftar di BEI periode tahun 20112015)

Diajukan untuk memenuhi syarat guna mencapai gelar Sarjana Akuntansi di Fakultas Ekonomi dan Bisnis Universitas Katolik Soegijapranata Semarang

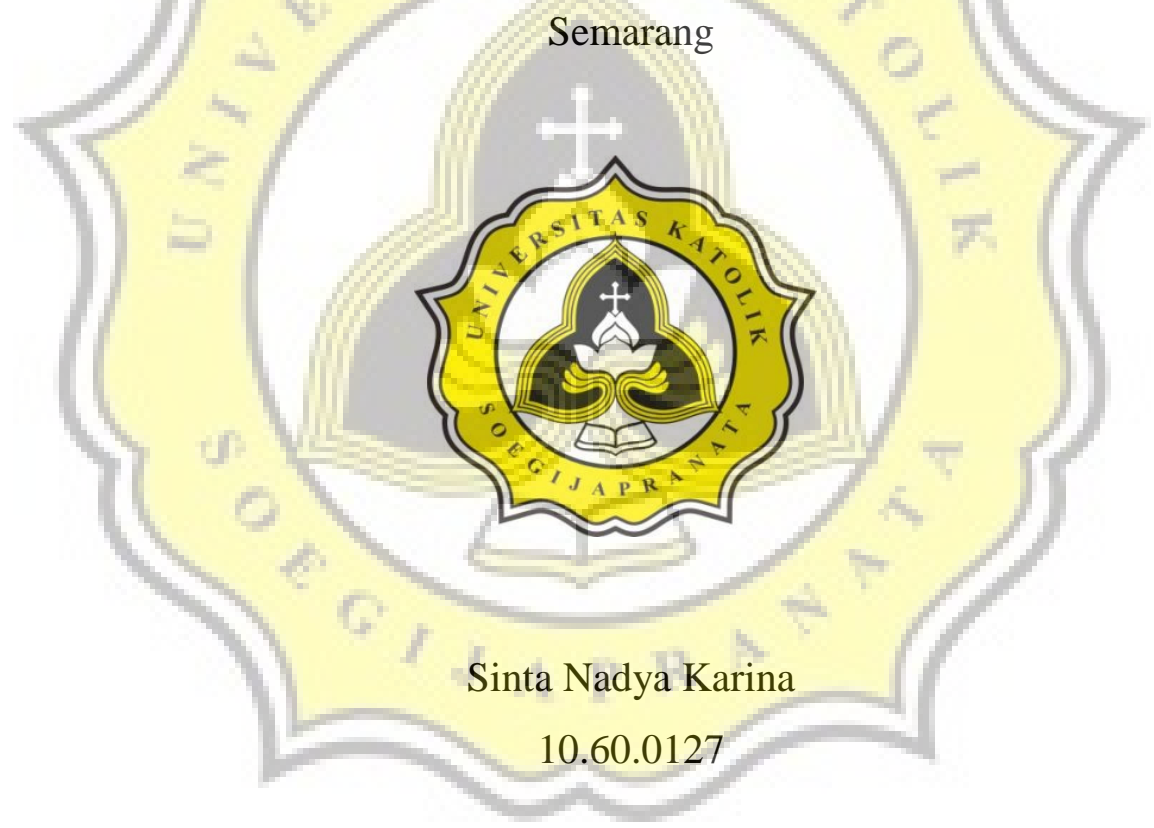

Fakultas Ekonomi dan Bisnis

Universitas Katolik Soegijapranata

Semarang

2018 
Skripsi dengan judul :

PENGARUH RISIKO KEUANGAN, DIVIDEN, KEPEMILIKAN MANAJERIAL, DAN REPUTASI AUDITOR TERHADAP PERATAAN

LABA

(Studi empiris pada perusahaan yang terdaftar di BEI periode tahun 2011 -

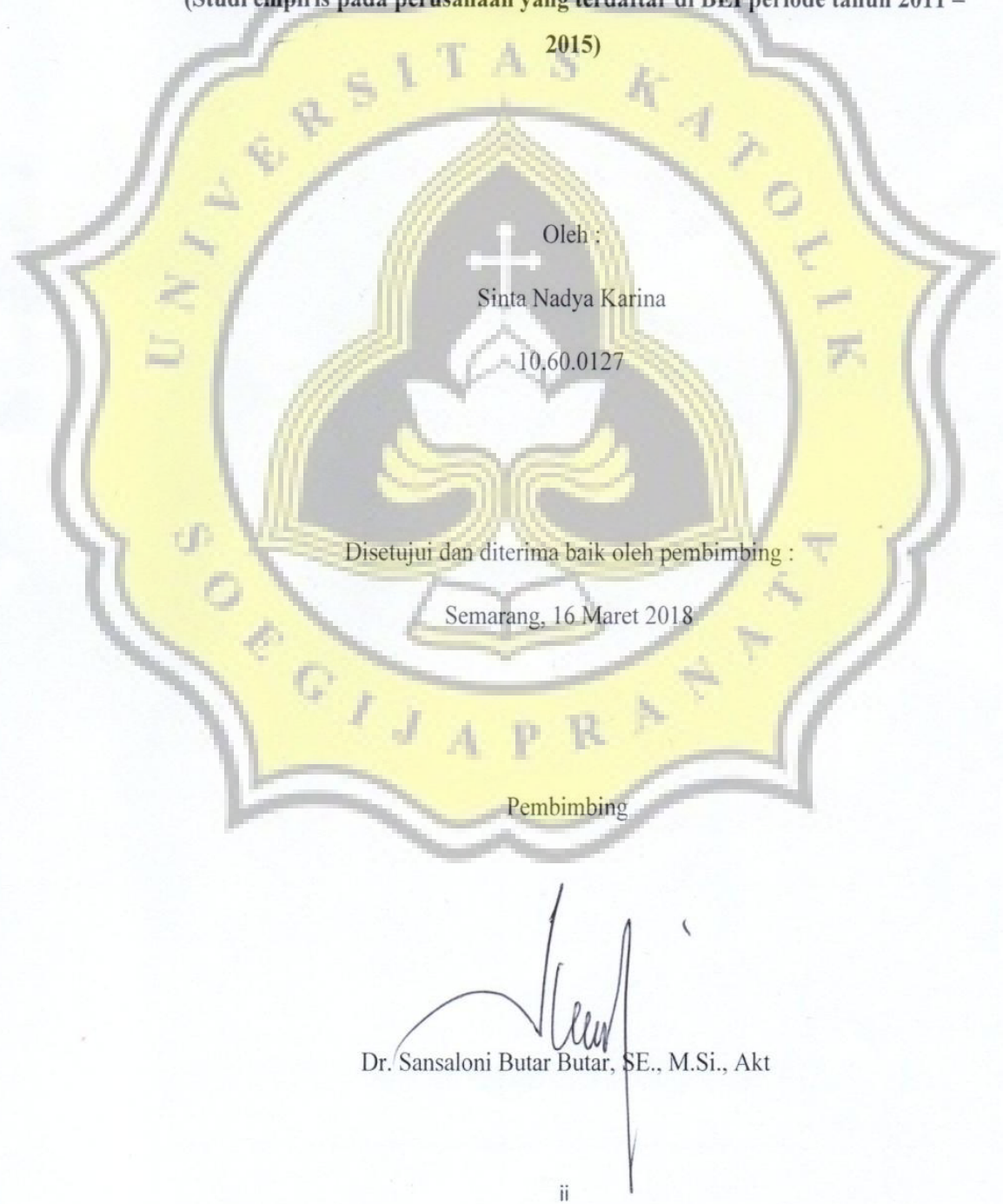


Telah diterima dan disahkan oleh panitia penguji pada :

Rabu, 16 Maret 2018

PENGARUH RISIKO KEUANGAN, DIVIDEN, KEPEMILIKAN

MANAJERIAL, DAN REPUTASI AUDITOR TERHADAP PERATAAN LABA

(Studi empiris pada perusahaan yang terdaftar di BEI periode tahun 2011 - 2015)

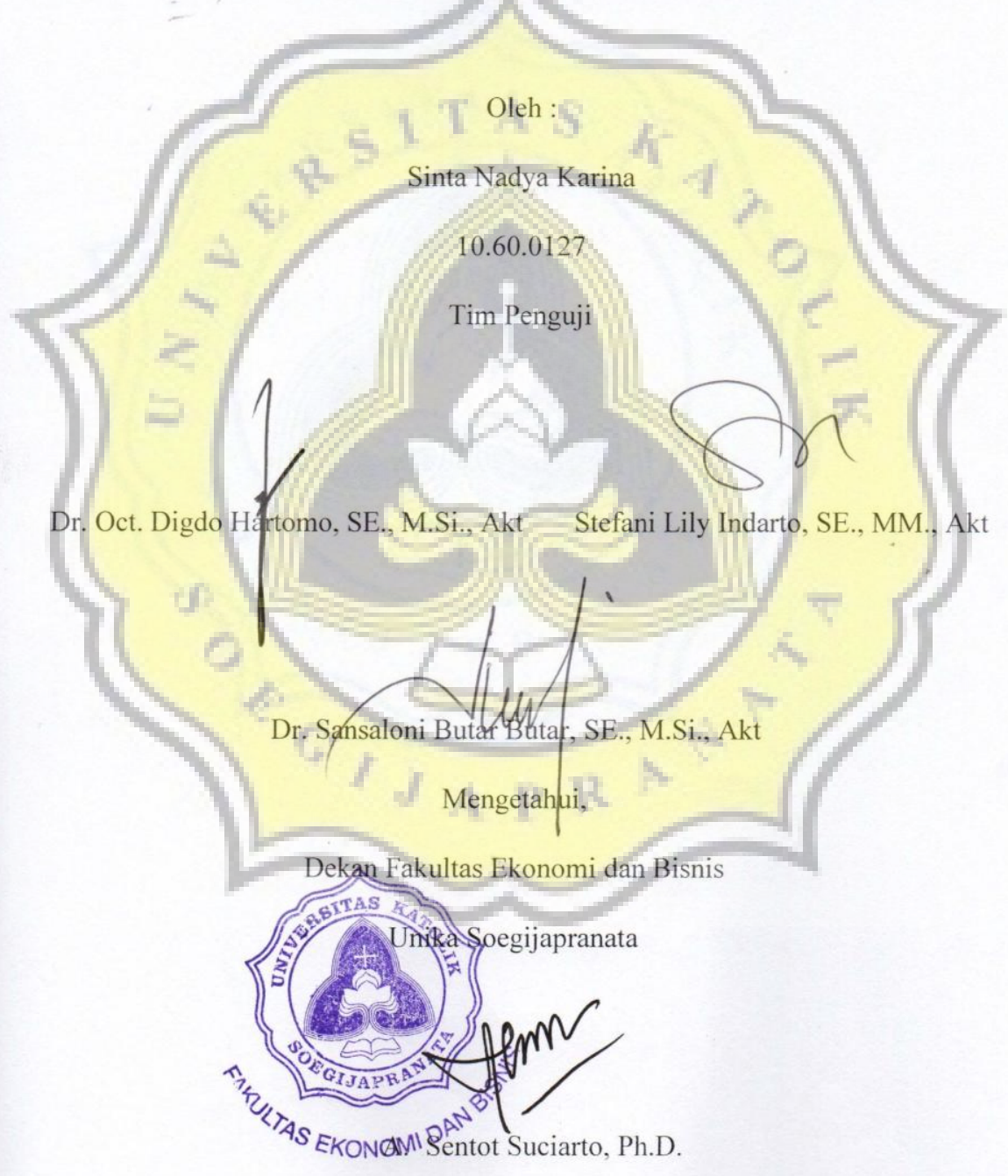

iii 


\section{PERNYATAAN KEASLIAN SKRIPSI}

Saya, yang bertanda tangan dibawah ini dengan sesungguhnya menyatakan bahwa skripsi dengan judul:

Pengaruh Risiko Keuangan, Dividen, Kepemilikan Manajerial dan Reputasi Auditor Terhadap Perataan Laba

(Studi empiris pada perusahaan yang terdaftar di BEI periode tahun 2011 2015)

Benar - benar merupakan karya saya. Saya tidak mengambil sebagian atau seluruh karya orang lain yang seolah - olah saya akui sebagai karya saya.

Apabila saya melakukan hal tersebut, maka gelar dan ijasah yang saya peroleh dinyatakan batal dan akan saya kembalikan kepada Universitas Katolik Soegijapranata.

Semarang, 16 Maret 2018

Yang menyatakan,

Sinta Nadya Karina 


\section{Kata Pengantar}

Puji Syukur kepada Tuhan Yang Maha Kuasa, penulis ucapkan karena skripsi dengan judul "Pengaruh Risiko Keuangan, Dividen, Kepemilikan Manajerial dan Reputasi Auditor Terhadap Perataan Laba (Studi empiris pada perusahaan yang terdaftar di BEI periode tahun 2011 - 2015)" telah dapat penulis selesaikan. Skripsi ini disusun untuk memenuhi syarat guna memperoleh gelar Sarjana Ekonomi pada Fakultas Ekonomi dan Bisnis Unika Soegijapranata Semarang. Topik ini dipilih karena perataan laba merupakan salah satu beban perusahaan besar maupun kecil. Oleh karena itu peneliti ingin menguji dan mengetahui apakah faktor - faktor risiko keuangan, dividen, kepemilikan manajerial dan reputasi auditor di dalam perusahaan dapat memberikan pengaruh atau tidak untuk menstabilkan laba didalam perusahaan. Skripsi ini berhasil menemukan bukti empiris bahwa pengaruh dari beberapa faktor diatas tidak sepenuhnya dapat mempengaruhi perataan laba. Oleh karena itu untuk penelitian selanjutnya diharapkan mengaitkan dengan peringkat ataupun kebijakan pemerintah tentang bunga yang ditetapkan oleh BI.

Selesainya skripsi ini peneliti akui tidak terlepas dari bantuan beberapa pihak. Untuk itu peneliti mengucapkan terima kasih kepada :

1. Dekan Fakultas Ekonomi dan Bisnis atas ijinnya kepada penulis untuk menggunakan fasilitas yang ada di Fakultas Ekonomi dan Bisnis

2. Ketua Jurusan Akuntansi atas dorongan dan dukungannya kepada penulis agar cepat menyelesaikan studi.

3. Bapak Dr. Sansaloni Butar Butar, M.Si. selaku Dosen Pembimbing yang selalu bersedia meluangkan waktu untuk berdiskusi dan membimbing penulis serta memberikan dorongan kepada penulis agar cepat menyelesaikan studi.

4. Orang tua tercinta yang selalu memberikan dorongan., mendukung, serta memberikan doa terbaiknya untuk penulis dalam menyelesaikan studi. 
5. Teman - teman semua, kakak penulis tercinta (Galuh Nuketha) dan kekasih tercinta (Vinsensius Rinda Resi) yang mendukung selama penulis menyelesaikan studi.

6. Semua saudara sepupu, teman seperjuangan bimbingan skripsi yang saling membantu dan membagi informasi, semua pihak yang tidak dapat disebutkan satu per satu, terimakasih atas dukungan serta bantuan kalian selama penulis menyelesaikan studi.

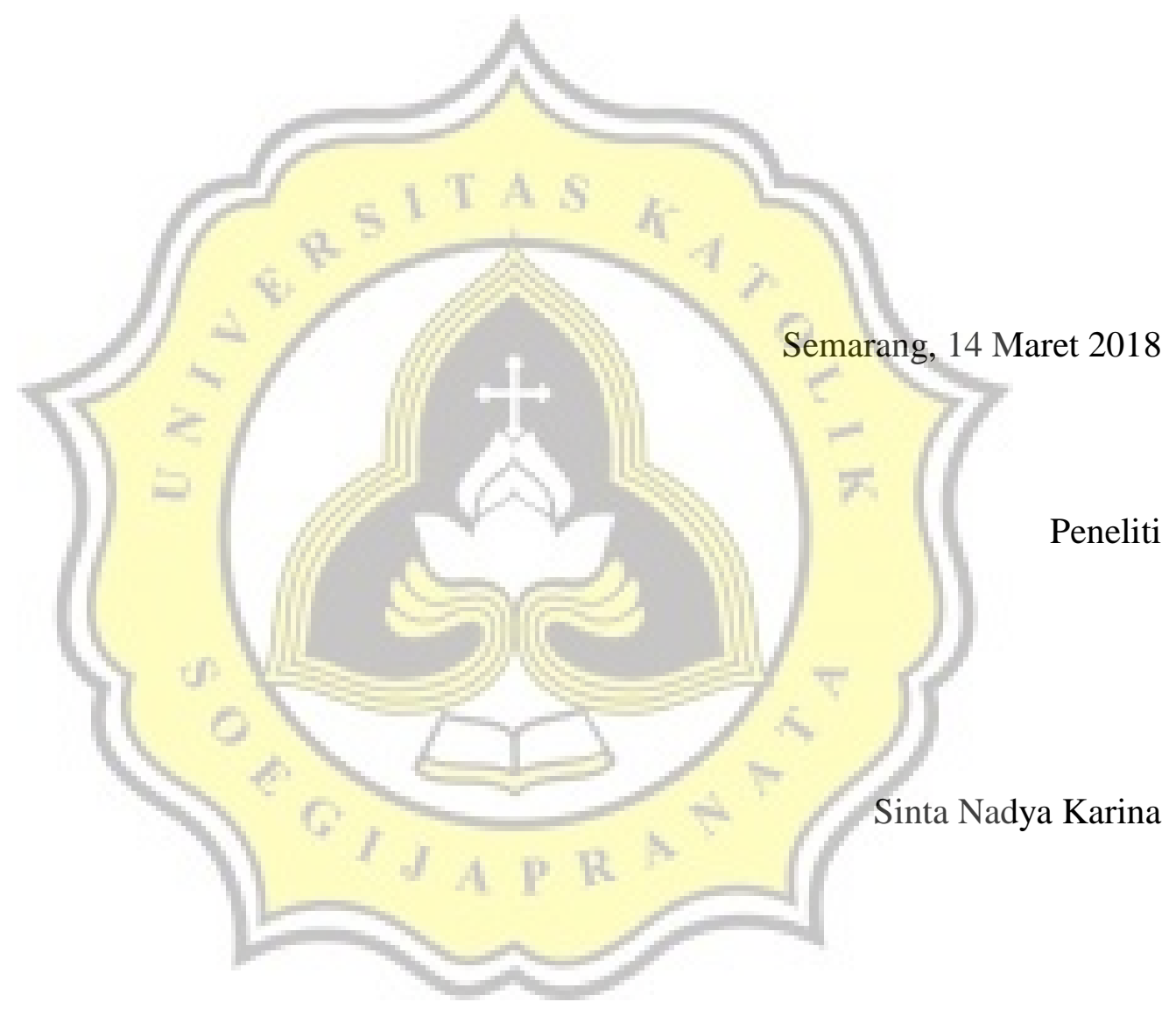




\section{DAFTAR ISI}

Halaman Judul. i

Halaman Persetujuan Error! Bookmark not defined.

Halaman Pengesahan Error! Bookmark not defined.

Surat Pernyataan Keaslian Skripsi ii

Kata Pengantar iii

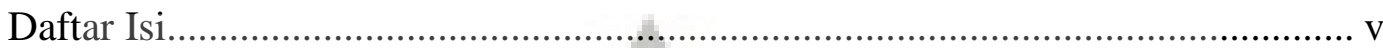

Daftar Gambar.................................................................................. vii

Daftar Tabel .................................................................................. viii

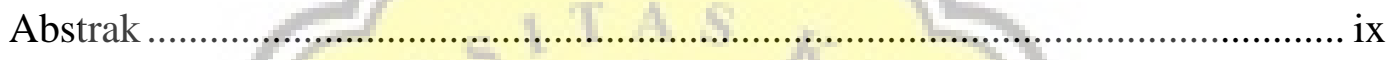

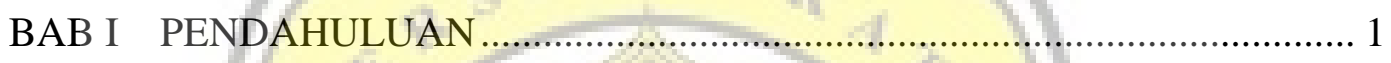

1.1 Latar Belakang Masalah....

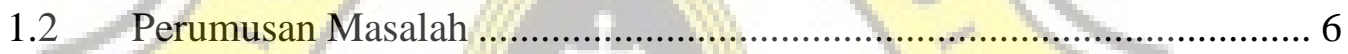

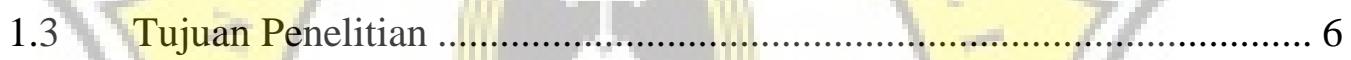

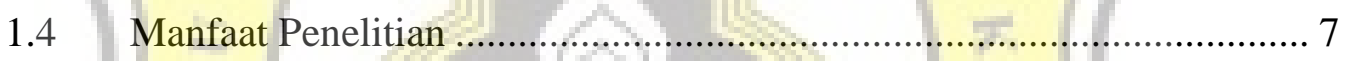

1.5 Kerangka Pikir Penulisan ................................................................. 7

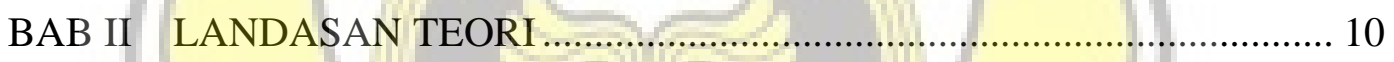

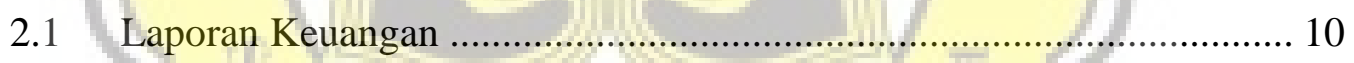

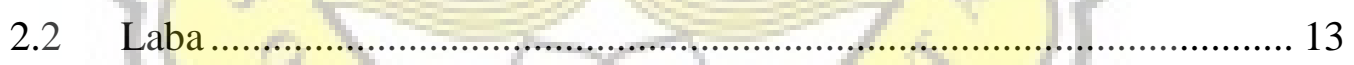

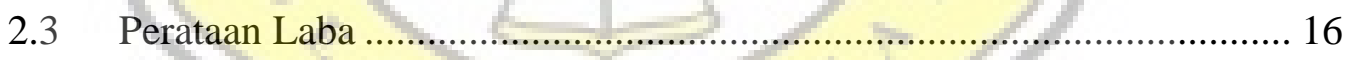

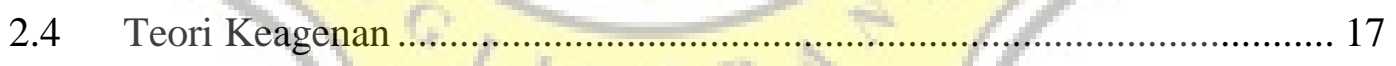

2.5 Teori Akuntansi Positif .................................................................. 19

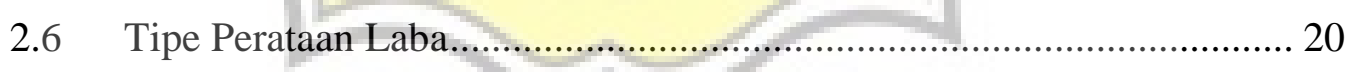

2.7 Sasaran Perataan Laba ....................................................................... 22

2.8 Alasan Dilakukannya Praktik Perataan Laba ...................................... 23

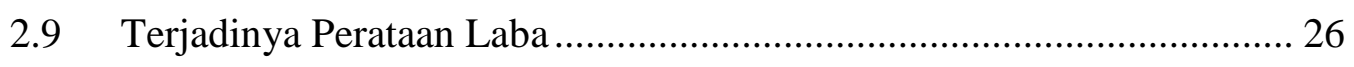

2.10 Tujuan Perataan Laba.................................................................... 27

2.11 Faktor-faktor yang Mempengaruhi Perataan Laba ............................ 29

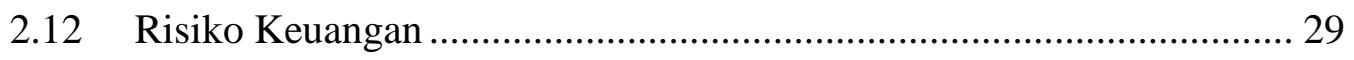

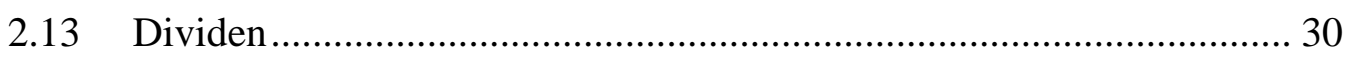

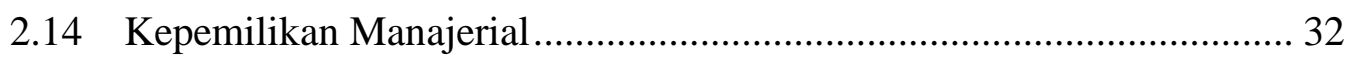

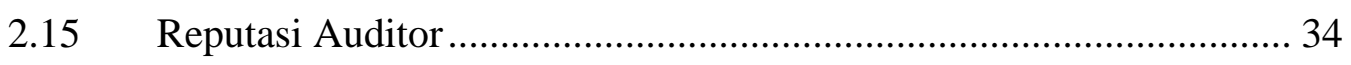




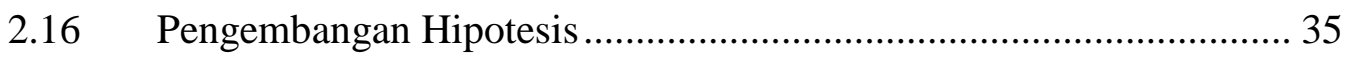

2.16.1 Pengaruh Risiko Keuangan terhadap Praktik Perataan Laba......... 35

2.16.2 Pengaruh Dividenterhadap Praktik Perataan Laba......................... 36

2.16.3 Pengaruh Kepemilikan Manajerial terhadap Praktik Perataan laba 37

2.16.4 Pengaruh Reputasi Auditor terhadap Praktik Perataan Laba .......... 39

BAB IIIMETODOLOGI PENELITIAN ....................................................... 41

3.1 Populasi dan Sampel Penelitian ..................................................... 41

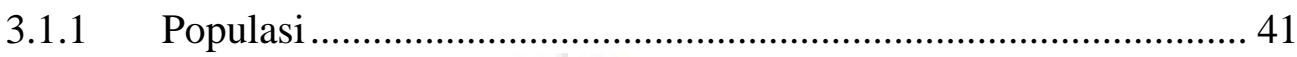

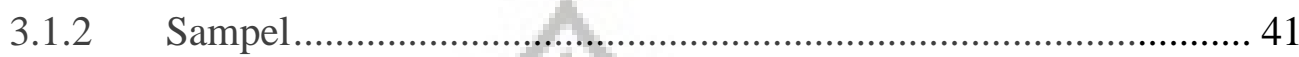

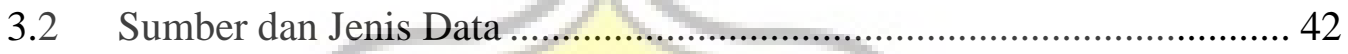

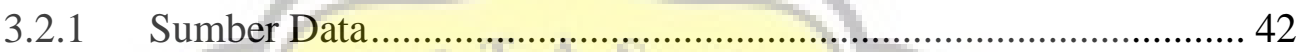

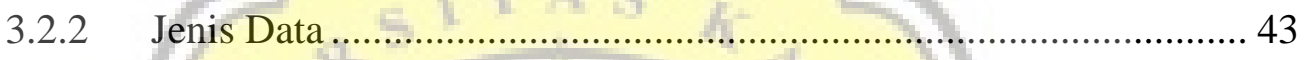

3.3 Definisi Operasional dan Pengukuran Variabel .................................. 43

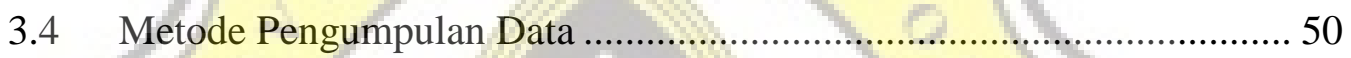

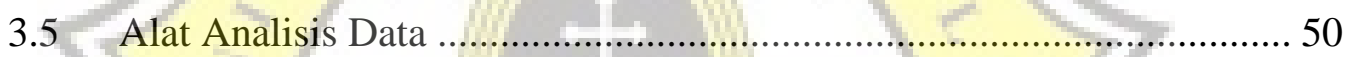

BAB IV HASIL PENELITIAN DAN PEMBAHASAN ................................. 54

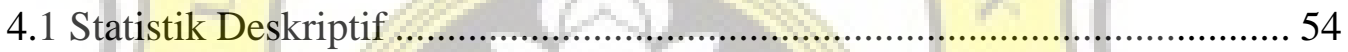

4.2 Pengujian Kelayakan Model (Goodness of Fit) ......................................... 58

4.2.1 Uji Hosmer and Lemeshow.......................................................... 58

4.2.2 Pengujian Keseluruhan Model ................................................... 59

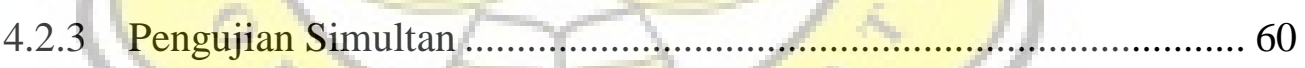

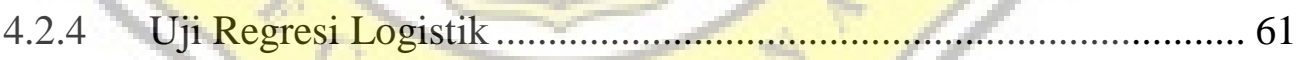

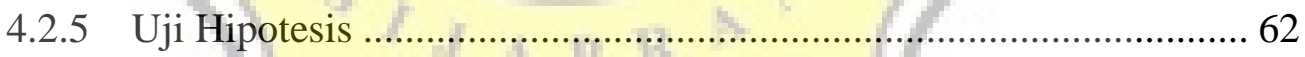

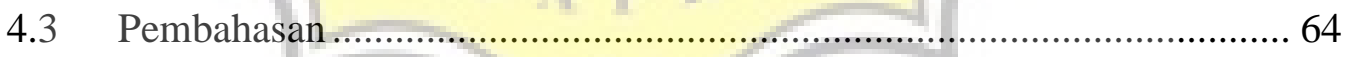

4.3.1 Pengaruh Risiko Keuangan terhadap Praktik Perataan Laba.............. 65

4.3.2 Pengaruh Dividenterhadap Praktik Perataan Laba.............................. 65

4.3.3 Pengaruh Kepemilikan Manajerial terhadap Praktik Perataan laba..... 66

4.3.4 Pengaruh Reputasi Auditor terhadap Praktik Perataan Laba .............. 67

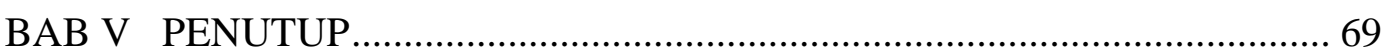

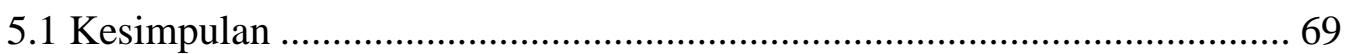

5.2 Keterbatasan dan Saran Penelitian .......................................................... 70

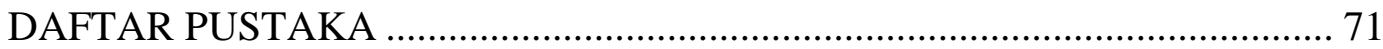

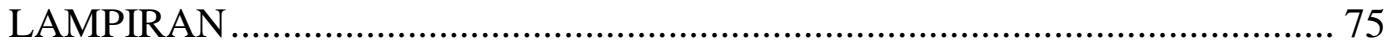




\section{DAFTAR GAMBAR}

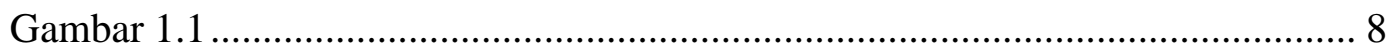

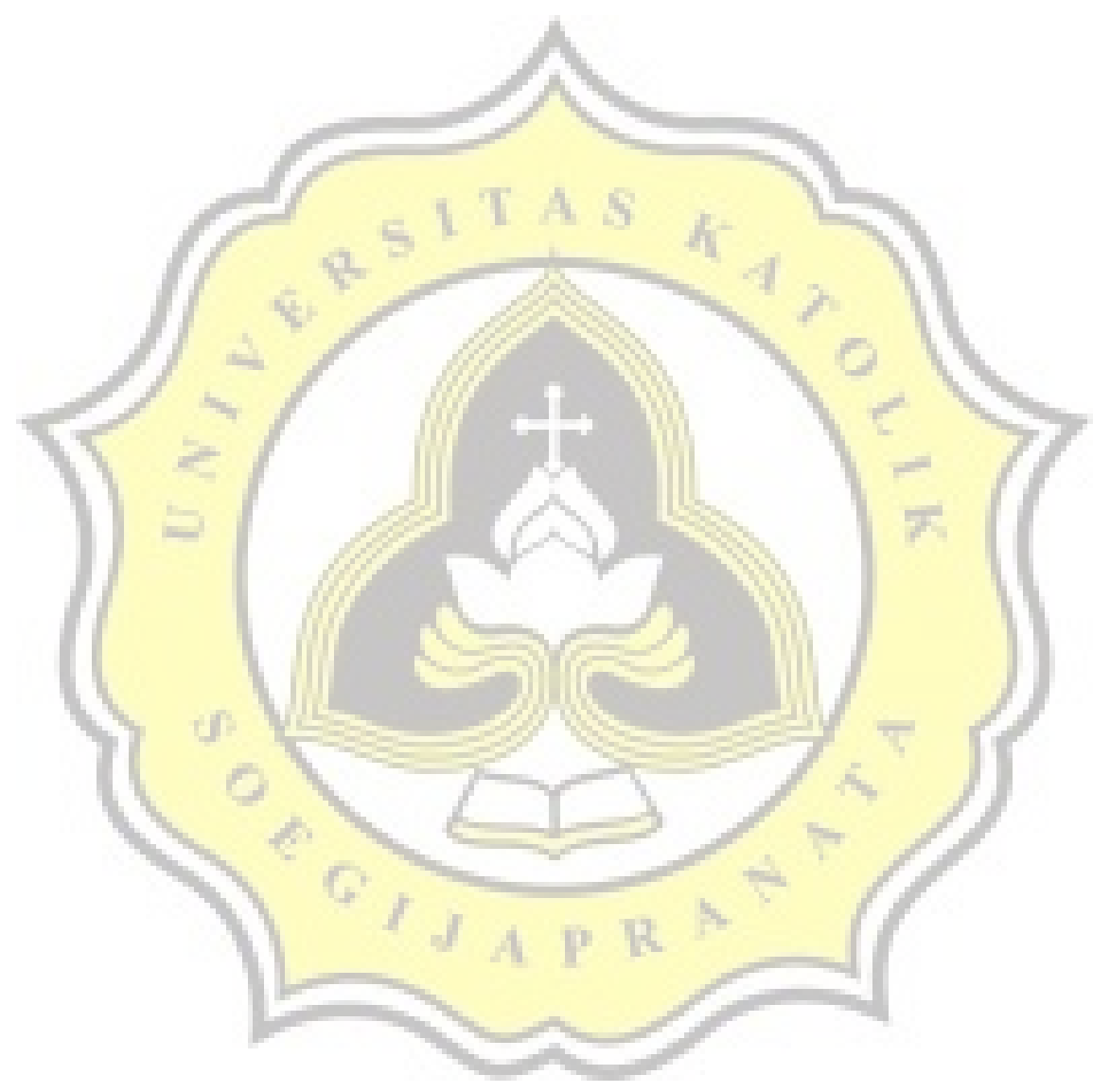




\section{DAFTAR TABEL}

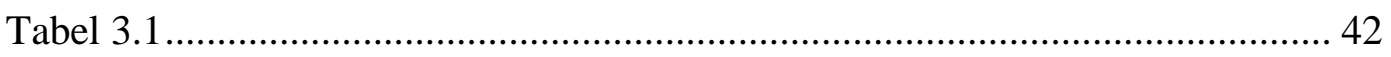

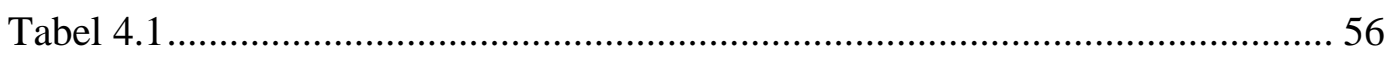

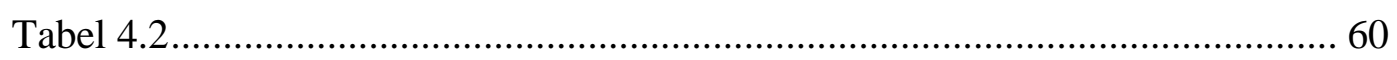

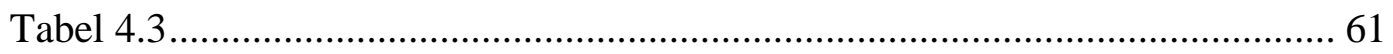

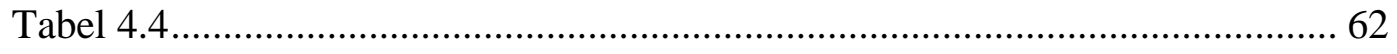

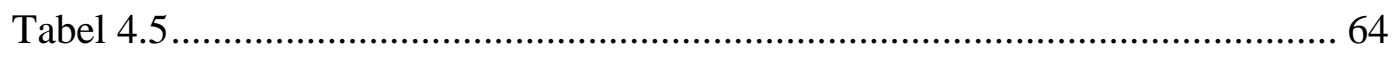

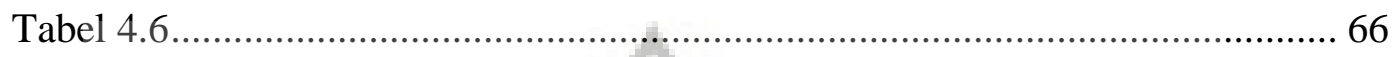

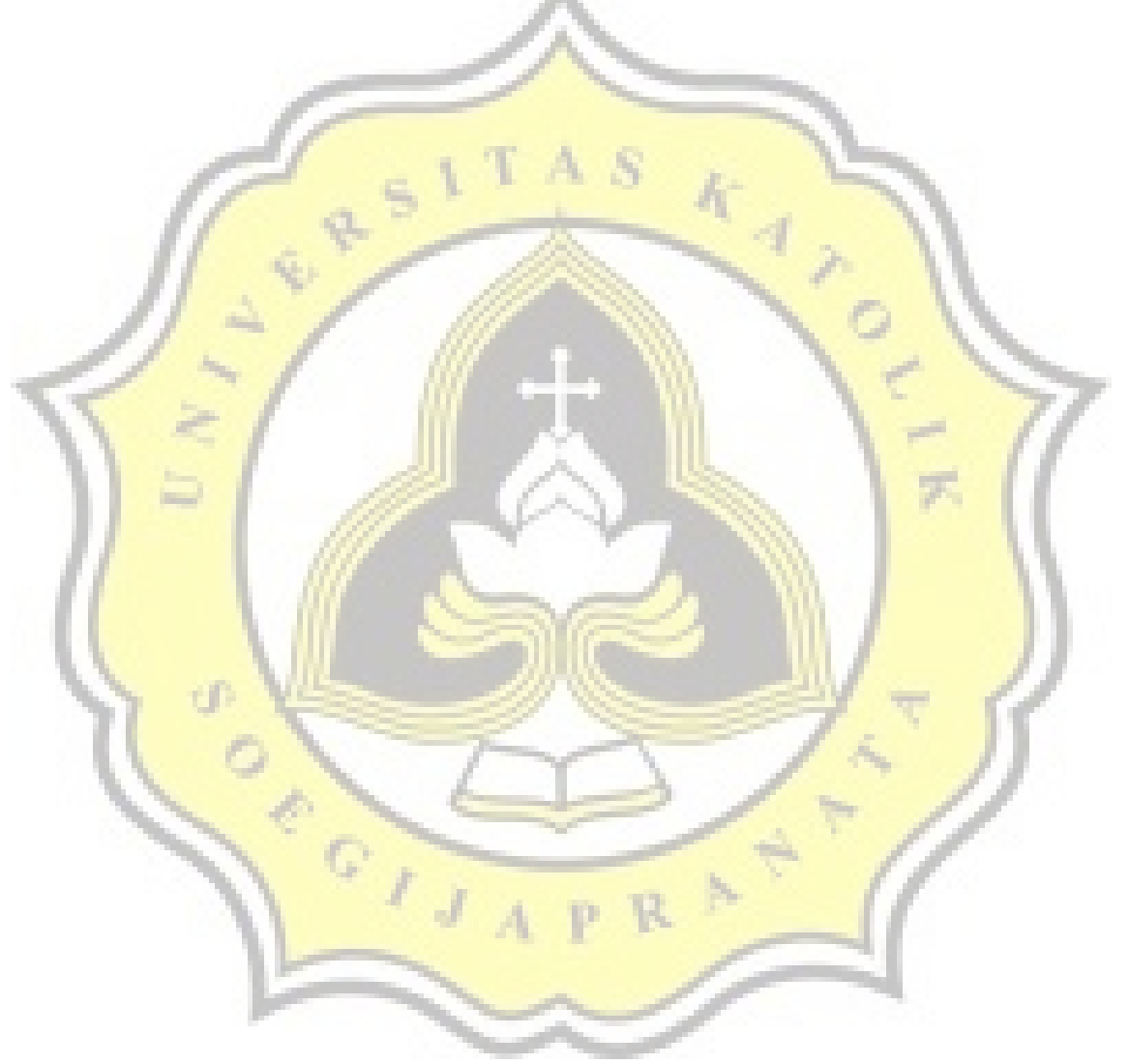




\begin{abstract}
ABSTRAK
Penelitian ini bertujuan untuk mengetahui pengaruh Risiko Keuangan, Dividen, Kepemilikan Manajerial dan Reputasi Auditor terhadap Perataan Laba yang menggunakan seluruh tipe perusahaan yang terdaftar di Bursa Efek Indonesia. Indeks Eckel digunakan untuk menentukan praktik perataan laba. Populasi dalam penelitian ini adalah semua perusahaan yang terdaftar di Bursa Efek Indonesia pada tahun 2011-2015. Hipotesis didalam penelitian ini menggunakan Regresi Logistik untuk mengetahui pengaruh risiko keuangan, dividen, kepemilikan manajerial dan reputasi auditor terhadap praktik perataan laba. Metode pengambilan sample dalam penelitian ini menggunakan data sekunder. Dalam penelitian ini juga ditambahkan variabel kontrol yaitu ukuran perusahaan, profitabilitas, dan financial leverage. Penelitian ini menyimpulkan bahwa dividen, kepemilikan manajerial dan reputasi auditor tidak berpengaruh signifikan terhadap praktik perataan laba.
\end{abstract}

Kata Kunci : Risiko Keuangan, Dividen, Kepemilikan Manajerial, Reputasi Auditor, Perataan Laba. 